\title{
8. CALCAREOUS NANNOFOSSIL BIOSTRATIGRAPHY OF MESOZOIC SEDIMENTS RECOVERED FROM THE WESTERN PACIFIC, LEG 129
}

\author{
Elisabetta Erba ${ }^{2}$ and James M. Covington ${ }^{3}$
}

\begin{abstract}
Calcareous nannofossils were studied from Jurassic and Cretaceous sediments drilled in the western Pacific during Ocean Drilling Program Leg 129. Mesozoic sediments at Sites 800, 801, and 802 are dominated by volcaniclastic turbidites, claystones, porcellanites, and radiolarites. Pelagic limestones are limited to the middle Cretaceous, and a few calcareous claystones were recovered in the Upper Jurassic section at Site 801.

We documented the distribution of nannofossils, their total abundance, preservation, and relative species abundance based on semiquantitative and qualitative studies. Preservation of the calcareous nannofloras is poor to moderate, and the total abundance fluctuates from rare to very abundant. Marker species proposed for the middle and Late Cretaceous were recognized, allowing the application of standard nannofossil biozonations.

At Site 800 calcareous nannofloras are abundant and moderately preserved in the Aptian-Cenomanian, and nannofossil biostratigraphy constitutes the basic stratigraphic framework for this interval.

Radiolarians are the most abundant and persistent group throughout the sequence drilled at Site 801. Long intervals are barren of nannofloras and assemblages are usually characterized by low abundance and poor preservation. Nannofossil biostratigraphy was applied to the upper Aptian-Cenomanian interval and a few marker species were recognized for the late Tithonian.

At Site 802 Cretaceous biostratigraphy is mainly based on calcareous nannofossil biozones corroborated by radiolarian and palynomorph events in the late Aptian-Coniacian age interval. A hiatus was indicated between the Santonian and the late Campanian, and another is suspected in the interval between the Cenomanian and the Coniacian.
\end{abstract}

\section{INTRODUCTION}

The objective of Ocean Drilling Program (ODP) Leg 129 was to recover the Jurassic oceanic crust of the Pacific plate. In the past 20 years, nine Deep Sea Drilling Project (DSDP) legs were devoted to this objective (for a synthesis see Lancelot, Larson, et al., 1990), but a thick sequence of middle Cretaceous intrusive basalts and dolerites, cherts, and thick volcaniclastic units prevented recovery of the mythical Jurassic crust. New seismic data reinforced the possibility of recovering the oldest oceanic crust of the Pacific plate and located a window where the Jurassic was drilled for the first time.

During Leg 129 three sites were drilled (Fig. 1). Site 800 is located in the northern Pigafetta Basin at $21^{\circ} 55.38^{\prime} \mathrm{N}, 152^{\circ} 19.37^{\prime} \mathrm{E}$, at a water depth of $5686 \mathrm{~m}$, and lies on magnetic anomaly lineation M33. Four lithostratigraphic units were identified in the Mesozoic interval below approximately $38 \mathrm{~m}$ of Cenozoic pelagic brown clays. The hole was terminated after penetrating a total of $498.1 \mathrm{~m}$ of sedimentary rocks and $46.4 \mathrm{~m}$ of dolerite sills with minor chert layers.

Site 801 is located in the central Pigafetta Basin at $18^{\circ} 38.56^{\prime} \mathrm{N}$, $156^{\circ} 21.57^{\prime} \mathrm{E}$, at a water depth of $5673.8 \mathrm{~m}$. It lies on the magnetic quiet zone southeast of a M25-M37 magnetic lineation sequence, and therefore is presumably older than Callovian. Below some $40 \mathrm{~m}$ of Quaternary to Paleocene pelagic brown clays the Cretaceous-Jurassic interval is represented by $405 \mathrm{~m}$ of sedimentary rocks overlying more than $129.3 \mathrm{~m}$ of basaltic oceanic crust.

Site 802 is located in the central Mariana Basin at $12^{\circ} 5.778^{\prime} \mathrm{N}$, $153^{\circ} 12.62^{\prime} \mathrm{E}$, at a water depth of $5968.6 \mathrm{~m}$, at the southeastern end of a magnetic lineation sequence partially identified to the northwest as M22 to M31, which suggests a Late Jurassic basement age. Here the Cenozoic consists of $14 \mathrm{~m}$ of pelagic brown clays, a thick sequence of volcaniclastic turbidites $(222.8 \mathrm{~m})$, and $92.5 \mathrm{~m}$ of nannofossil chalk. The Mesozoic is represented by $110.8 \mathrm{~m}$ of Upper Cretaceous

\footnotetext{
${ }^{1}$ Larson, R. L., Lancelot, Y,, et al., 1992. Proc. ODP, Sci. Results, 129: College Station, TX (Ocean Drilling Program)

2Dipartimento di Scienze della Terra, Via Mangiagalli 34, I-20133 Milano, Italy.
}

volcaniclastic turbidites and $49.2 \mathrm{~m}$ of middle Cretaceous calcareous claystones and radiolarites, overlying $50.6 \mathrm{~m}$ of basalts.

The Mesozoic sediments recovered were dated mainly on the basis of calcareous nannofossils and radiolarians, with minor contributions by foraminifers. Palynomorphs were identified only in the oldest sediments recovered at Sites 802, in Cores 129-802A-56R and 129802A-57R

In this paper we document the occurrence, preservation, and abundance of calcareous nannofossils in the Jurassic and Cretaceous.

\section{MATERIALS AND METHODS}

Semiquantitative analyses of Mesozoic nannofossil assemblages were performed on a total of 538 samples collected from different lithologic types. The nannofossil assemblages were analyzed in smear slides with a polarizing light microscope, at $1250 \times$ magnification. Preparation was kept simple and smear slides were prepared directly from the sediment samples.

The total abundance of nannofossils was estimated by comparing their occurrence with those of the other biogenic particles and inorganic components. The following letter codes were adopted:

For total abundance, $\mathrm{V}=$ very abundant $(>50 \%$ of the fine fraction), $\mathrm{A}=$ abundant ( $30 \%$ to $50 \%$ of the fine fraction), $\mathrm{C}=$ common ( $12 \%$ to $30 \%$ of the fine fraction), $\mathrm{F}=$ few ( $2 \%$ to $12 \%$ of the fine fraction), $\mathrm{R}=$ rare $(<2 \%$ of the fine fraction), $\mathrm{B}=$ barren.

The relative abundance of the individual nannofossil species was tabulated in the range charts as follows: $\mathrm{V}=$ very abundant (more than 10 specimens per field of view), $A=$ abundant ( $1-10$ specimens per field of view), $\mathrm{C}=$ common ( 1 specimen per 2-10 fields of view), $\mathrm{F}$ $=$ few $(1$ specimen per $11-100$ fields of view $), R=$ rare $(1$ specimen per 101-1000 fields of view).

Estimates of preservation were based on the degree of etching, overgrowth, and breakage, and letter codes were assigned as follows: $\mathrm{G}=$ good (overgrowth and/or etching are virtually absent; nannofossils retain all the diagnostic characteristics), $\mathrm{M}=$ moderate (overgrowth and/or etching have partially altered the ultrastructure of nannofossils, but diagnostic features are preserved), $\mathrm{P}=$ poor (over- 


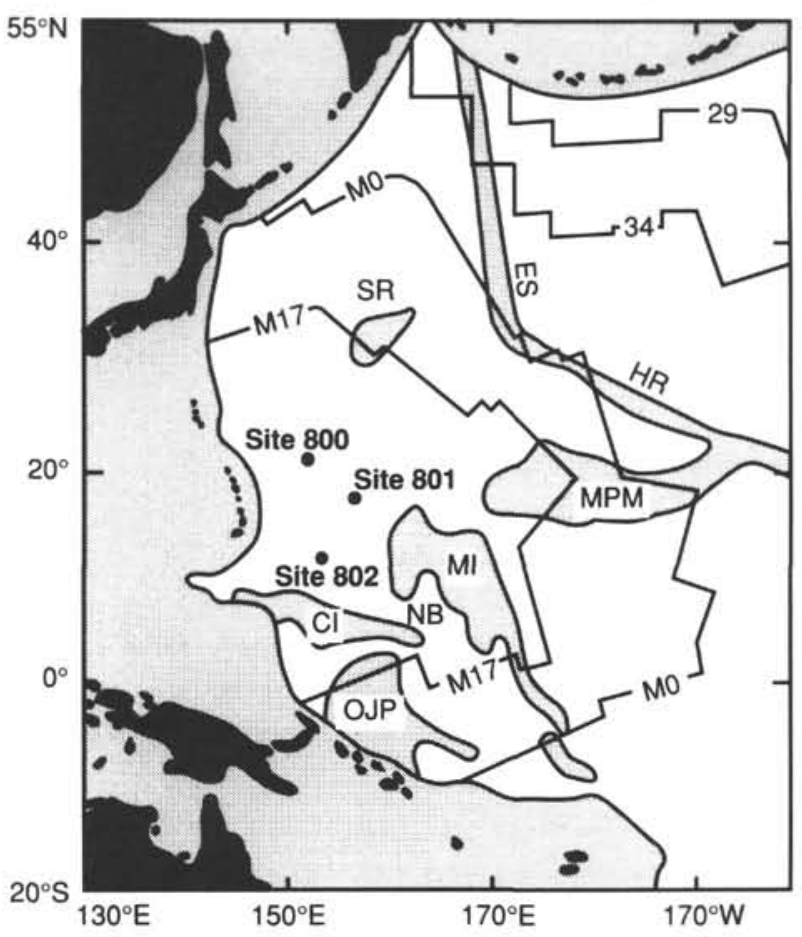

Figure 1. Location of Sites 800, 801, and 802 drilled during Leg 129. Bedrock isochrons are determined from magnetic anomaly lineation mapping of the Pacific plate. Unshaded areas represent normal Pacific oceanic crust, shaded areas represent volcanic edifices with thickened crustal sections, as well as younger areas beyond the Pacific subduction zones (after Lancelot, Larson, et al., 1990). SR = Shatsky Rise; ES = Emperor Seamounts; HR = Hawaiian Ridge; $M P M=$ Mid-Pacific Mountains; $\mathrm{MI}=$ Marshall Islands; $\mathrm{CI}=$ Caroline Islands; $\mathrm{NB}=$ Nauru Basin; OJP = Ontong Java Plateau

growth, etching, and/or fragmentation have highly altered nannofossil ultrastructure).

All the species considered in this report and tabulated in the range charts are listed in the Appendix ordered by the specific epithets.

\section{PRESERVATION OF CALCAREOUS NANNOFLORAS}

Calcareous nannofossils are important constituents of pelagic carbonates since at least Jurassic times. They also occur in Triassic sediments (e.g., Bown, 1987; Bralower et al., 1991) but are sparse and constitute only a minor portion in pelagic micrite. Nannofloras increased in abundance and diversity through the Jurassic, and in the Tithonian they experienced a superbloom to become the major contributors to pelagic carbonates. Because nannoplankton is part of the phytoplankton community, nannofossils have been used in paleoceanography to reconstruct surface-water conditions and their changes through time. Moreover, calcareous nannofossil assemblages can provide information on the type and degree of diagenetic modification experienced by pelagic carbonates. In fact, their abundance, species diversity, and composition can put constraints on the secondary alterations superimposed on the primary inputs.

The overall preservation of Mesozoic nannofossils from Sites 800 , 801 , and 802 is generally poor with a few intervals characterized by moderate preservation. Long intervals of the sedimentary sequences underwent severe dissolution as documented by the high number of barren samples (Table 1). The dissolution/diagenesis resistant Watznaueria barnesae is always the dominant taxon and even it is exclusive in a few samples. The low abundance and poor preservation of nannofloras probably reflect a deep depositional paleoenvironment
Table 1. Samples investigated for Mesozoic calcareous nannofossils at Sites 800,801 , and 802 .

\begin{tabular}{ccc} 
Site & Number of studied samples & Number of barren samples \\
\hline 800 & 215 & $107(49.7 \%)$ \\
801 & 164 & $109(66.5 \%)$ \\
802 & 159 & $45(28.3 \%)$ \\
\hline
\end{tabular}

in an oceanic setting with important volcaniclastic inputs. The nannofloral assemblages might also reflect primary fluctuations controlled by the position of the drilled sites with respect to the paleoequator and possible fluctuations of carbonate vs. siliceous biogenic production. Indeed, equator crossings occurred at the three sites at different times during the Mesozoic. The paleoequatorial communities were dominated by radiolarians, which sporadically are the only microfossils preserved (Lancelot, Larson, et al. 1990; Erba, this volume). This situation is exacerbated by drilling because the poor recovery emphasizes the harder cherty lithology rather than the interbedded soft chalks or limestones.

As regards the Jurassic section drilled at Site 801, the lithology recovered is siliceous throughout with only scanty calcareous layers. These data might confirm that nannofossils became important producers of pelagic carbonates only in the late Tithonian. However, the paleodepth and paleolatitude of Site 801 might be more important factors controlling the type of organisms preserved in the Jurassiclowermost Cretaceous sediments.

Nannofossil preservation will be discussed from the oldest to the youngest sediments, at each site.

\section{Site $\mathbf{8 0 0}$}

At Site 800 the oldest sediments overlying the dolerite sills consist of Berriasian-Barremian clays and radiolarites and therefore, Cores 129$800 \mathrm{~A}-56 \mathrm{R}$ to $129-800 \mathrm{~A}-51 \mathrm{R}$ are barren of calcareous nannofossils. The interval recovered in Cores 129-800A-50R to 129-800A-38R consists of volcaniclastics containing sparse nannofloras dominated by Watznaueria barnesae, with minor contributions by other robust species such as Cretarhabdus surirellus. Abundance is extremely low and diversity reaches a maximum value of six species in Sample 129-800A-39R-4, $30 \mathrm{~cm}$. In this interval nannofossils show evidence of strong etching and minor secondary overgrowth.

Upward, from Core 129-800A-37R to Section 129-800A-33R-2, the nannofossil total abundance fluctuates from rare to common and diversity is as high as 16 species. Also in this interval species relatively sensitive to dissolution/diagenesis were encountered. Nevertheless, preservation remains poor and a few samples are barren of calcareous nannofossils.

A second dissolution pulse is recorded in the upper lower Aptian, from Core 129-800A-32R to Section 129-800A-27R-2, where most samples are barren of nannofossils. Only Sample 129-800A-28R-3, $24-25 \mathrm{~cm}$, contains common moderately preserved nannofossils. In all the other nannofossil-bearing layers from this interval, diversity is very low. Nannofloras are rare to abundant in the upper Aptian and preservation is moderate. Throughout this interval diversity is relatively high, with a maximum value of 27 species in Sample 129800A-26R-1, 18-20 cm.

In the lower and middle Albian nannofossils are slightly less abundant and diversified, and preservation is poor. An increase in abundance is recorded in the upper Albian to Cenomanian interval, where nannofloras display moderate to good preservation. Cores $129-800 \mathrm{~A}-13 \mathrm{R}$ to $129-800 \mathrm{~A}-11 \mathrm{R}$, dated as Cenomanian mainly by radiolarians, contain rare nannofossils characterized by low species diversity and poor preservation.

The Turonian to upper Campanian interval is represented by cherts and porcellanites barren of calcareous nannofossils with the exception of Sample 129-800A-6R-1, 3-4 cm, in which rare specimens of $W$. barnesae were observed. 


\section{Site 801}

Site 801 is the first drill site at which Jurassic sediments overlying oceanic crust from the Pacific plate were recovered. The Jurassic section consists of red radiolarites, clays, and brown radiolarites virtually barren of calcareous nannofossils. In fact, only eight samples in the interval represented by Cores 129-801B-43R to 129-801B-19R contain rare nannofossils, which are characterized by poor preservation and low diversity. Nannofossils are absent in the BerriasianValanginian brown radiolarites and in the overlying volcaniclastic turbidites of Cores 129-801B-13R to 129-801B-10R.

This barren portion is overlain by a short interval (Cores 129801B-9R and 129-801B-8R) with rare, poorly preserved nannofossils. Only Sample 129-801B-8R-4, 111-112 cm, contains a more abundant and moderately preserved nannoflora with a relatively high diversity. The Albian to Cenomanian interval is characterized by more abundant and better preserved nannofossils recording high diversity. Assemblages also contain species sensitive to diagenesis. In particular, nannofossils are abundant in the interval recovered in Cores $129-801 \mathrm{~A}-19 \mathrm{R}$ to $129-801 \mathrm{~A}-14 \mathrm{R}$, which is dated as late Albian-Cenomanian.

The upper part of the Cretaceous, assigned to the CenomanianMaestrichtian from radiolarians, consists of brown cherts and porcellanites barren of calcareous nannofossils.

\section{Site 802}

Calcareous nannofossils are the dominant group in the Cretaceous section recovered at Site 802. Total abundance fluctuates from barren to very abundant, whereas preservation is usually poor. The oldest sediments overlying the basalts consist of claystones and volcaniclastic turbidites (Cores 129-802A-56R and 129-802A-57R) and are assigned to the late Aptian-Albian by integrated nannofossil-palynomorph biostratigraphy. In this portion of the drilled sequence nannofossils are rare and poorly preserved with strong evidence of etching.

The overlying interval, represented by calcareous claystones and radiolarian limestones in Cores $120-802 \mathrm{~A}-55 \mathrm{R}$ to $129-802 \mathrm{~A}-53 \mathrm{R}$, contains common to very abundant nannofloras of late Albian to Cenomanian age. Diversity is relatively high but preservation is still poor. Strong etching is recorded in the clayey layers, whereas overgrowth is dominant in the limestones.

A dissolution event characterizes Cores 129-802A-52R through Sample 129-802A-51R-1, 145-146 cm, dated as Cenomanian by radiolarians.

The Upper Cretaceous is represented by volcaniclastic turbidites underlying a thin pelagic clayey unit. Calcareous nannofossils are rare to very abundant and preservation fluctuates from poor to moderate. Usually the clayey layers show evidence of dissolution, whereas limestones display strong overgrowth. The highest abundances are recorded in Cores 129-802A-43R and 129-802A-38R, which were dated as Santonian and late Campanian, respectively. Here the assemblages are well diversified and delicate taxa occur commonly. Cores 129-802A-41R and 129-802A-40R are virtually barren of nannofossils, which are represented in only a few layers by common $W$. barnesae and other dissolution-resistant forms.

\section{BIOSTRATIGRAPHY}

In the last two decades calcareous nannofossils have become the premier guide fossils for age dating and correlating of Mesozoic pelagic carbonates.

After the first zonal scheme published by Barnard and Hay (1974), several nannofossil zonations were proposed for the Jurassic (Thierstein, 1976; Medd, 1982; Roth et al., 1983; Perch-Nielsen, 1985) and new, much more refined schemes have been proposed recently (Bown, 1987; Bown et al, 1988). The rare Jurassic nannofossils observed in sediments recovered during Leg 129 occur in the Oxfordian-Tithonian interval, in addition to sparse specimens of Watznaueria in older layers. For the Late Jurassic we used the scheme proposed by Bralower et al. (1989), who calibrated nannofossil events with magnetic anomalies.

Cretaceous nannofossil biostratigraphy has reached considerable stability and cosmopolitan zonations have been proposed (Thierstein, 1976; Sissingh, 1977; Roth, 1978; Perch-Nielsen, 1985). Although their resolution is relatively low, these basic zonations are reliable and reproducible worldwide and have been proven extremely useful for correlation. A number of much more detailed nannofossil biostratigraphy zonations were proposed for various paleoprovinces (e.g., Boreal realm; Mortimer, 1987; Jakubowski, 1987; Crux, 1989) or individual sedimentary basins but their application is necessarily geographically restricted.

Figure 2 summarizes the Cretaceous nannofossil zonation scheme adopted for this study and previously used for Leg 129 (Lancelot, Larson, et al., 1990). We applied the zonation of Thierstein (1971, 1973) for the Early Cretaceous and the events proposed by Thierstein (1976) and Monechi and Thierstein (1985) for the Late Cretaceous. Slight modifications of these biostratigraphic schemes were adopted as proposed by Sissingh (1977) and Roth $(1978,1983)$ who introduced letter codes and numbers for the biozones. Correlation of nannofossil events with magnetic anomalies is based on Bralower (1987) and Channell and Erba (in press) and on Monechi and Thierstein (1985) for the Lower and Upper Cretaceous, respectively.

\section{Site 800}

In the Mesozoic sequence recovered at Site 800, calcareous nannofossils occur in lithologic Units IV and III, dated as middle Cretaceous. Table 2 (in the back pocket of this volume) reports the abundance, preservation, and species distribution of nannofossils from this site.

The lower part of the drilled sequence is barren of calcareous nannofossils, which were first observed in Sample 129-800A-42R-2, 16-17 cm. $W$. barnesae is the exclusive or dominant form in the poorly preserved unzoned interval extending upward to Sample 129-800A-38R-2, 33-34 $\mathrm{cm}$. Other species recorded in this interval are Cyclagelosphaera margerelii, Watznaueria britannica, Watznaueria supracretacea, Diazomatolithus lehmanii, and Rucinolithus terebrodentarius. Rucinolithus irregularis is the oldest marker species, which was observed in Sample 129-800A-38R$1,105 \mathrm{~cm}$, and suggests an age not older than early Aptian. We used the first occurrence of this taxon to identify the base of the Chiastozygus litterarius/NC6/CC7 Zone, which is equated to the Barremian/Aptian boundary (Thierstein, 1973). Two additional events, namely the first occurrence of Chiastozygus litterarius and the last occurrence of Nannoconus colomii (or N. steinmannii), proposed for the identification of this boundary, could not be used in this study. In fact, $C$. litterarius is very rare and taxonomic problems might arise in differentiating this species from other poorly preserved Chiastozygus reported from older sediments (Bralower, 1987). Also, nannoconids are extremely rare and their occurrence seems to be controlled by resedimentation from shallower sites. The upper limit of the $C$. litterarius/NC6 Zone, based on the first occurrence of Lithastrinus floralis and/or Parhabdolithus angustus, extends upward to Sample 129-800A-27R-1, $111 \mathrm{~cm}$. Nannofossil assemblages in this zone are relatively diversified although dominated by the Watznaueria group.

The interval from Samples $129-800 \mathrm{~A}-27 \mathrm{R}-1,111 \mathrm{~cm}$, to $129-800 \mathrm{~A}$ 24R-CC is assigned to the Parhabdolithus angustus/NC7 Zone. The base of this zone is correlatable with the early/late Aptian boundary. We identified the lower boundary of this nannofossil zone with the first occurrence of Lithastrinus floralis, whereas $P$. angustus was first observed in Sample 129-800A-26R-2, 102-104 cm. In this zone nannofossils are more abundant, better preserved, and more diversified. An increase in abundance of $R$. irregularis was observed in the central part of the zone, within Core 129-800A-26R. Assipetra infracretacea disappears at the top of this zone.

Zone CC7 of Sissingh's (1977) zonation corresponds to the two zones discussed in the previous section. 


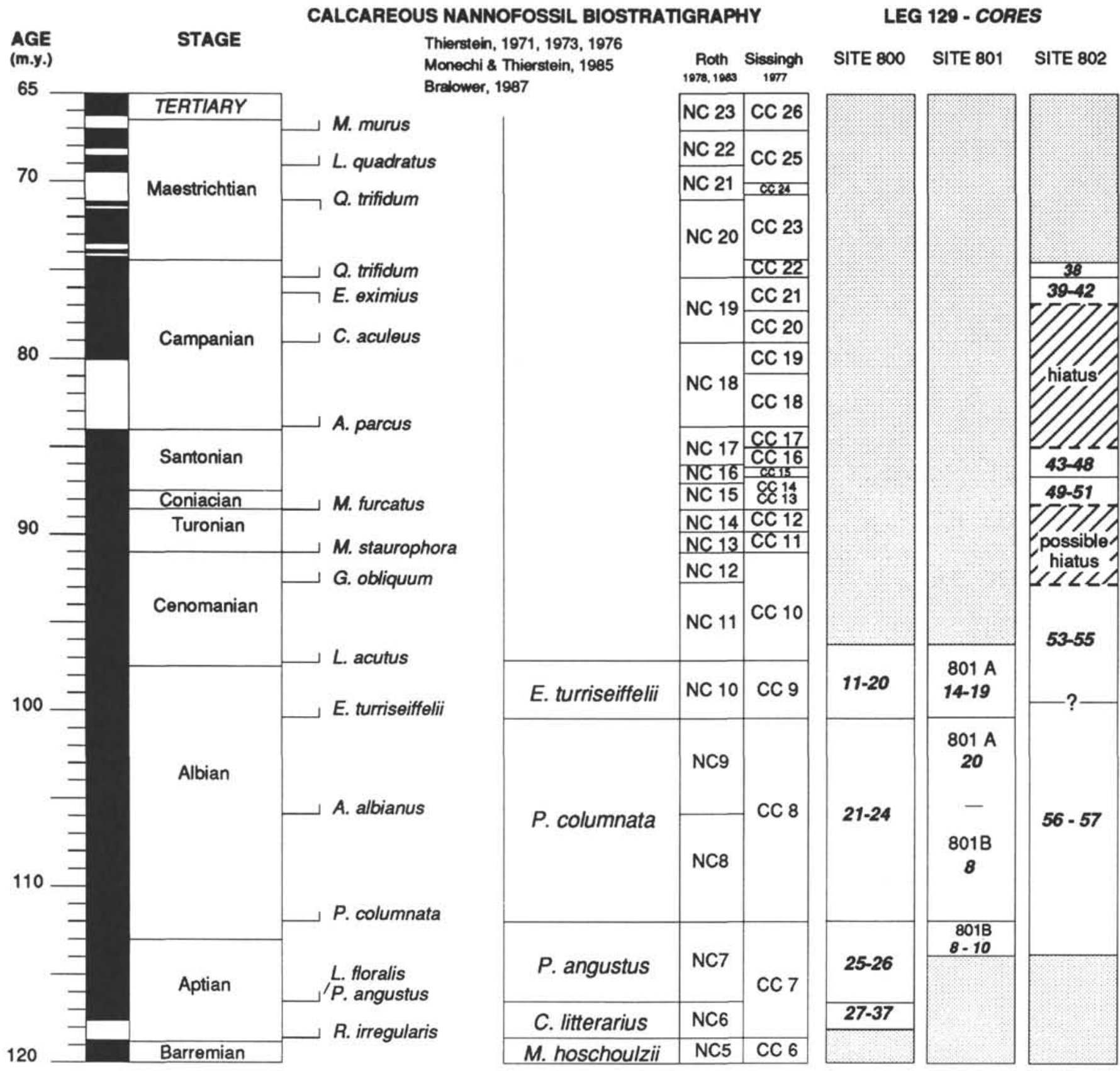

Figure 2. Synthesis of nannofossil biostratigraphy applied to the Cretaceous sediments recovered at Sites 800,801 , and 802 . Absolute ages, chronology, and magnetic polarity sequence after Kent and Gradstein (1985).

The first appearance of Prediscosphaera columnata, defining the base of the $P$. columnata/NC8/CC8 Zone, occurs in Sample 129-800A$24 \mathrm{R}-1,86-87 \mathrm{~cm}$, within the lower portion of lithologic Unit III. It is not possible to determine the Aptian/Albian boundary using calcareous nannofossils, but the first occurrence of $P$. columnata has always been regarded as an early Albian event. Therefore, the Aptian/Albian boundary should be placed in the upper portion of the $P$. angustus/NC7/CC7 Zone and could coincide with the boundary between lithostratigraphic Units IV and III. Consequently, a hiatus could not be ruled out at this interval.

The $P$. columnata/NC8/CC8 Zone extends to Sample 129-800A$21 \mathrm{R}-2,3 \mathrm{~cm}$, where Eiffellithus turriseiffelii was first observed. This event is used to define the base of the E. turriseiffelii/NC10/CC9 Zone. Roth (1978) proposed the first occurrence of Axopodorhabdus albianus to identify the base of his NC9 Zone and Thierstein (1976) used this event as marker in the middle Albian. A. albianus is extremely rare at Site 800 and occurs only in the overlying zone. According to Perch-Nielsen (1985), an alternative middle Albian event is the first occurrence of Tranolithus orionatus, which was recorded in Sample 129-800A-23R-1,21-22 cm. In the $P$. columnata Zone we also observed the first occurrences of small Eiffellithus closely resembling E. eximius and of Biscutum blackii.

The interval corresponding to Samples 129-800A-21R-2, $3 \mathrm{~cm}$, through $129-800 \mathrm{~A}-11 \mathrm{R}-1,11-13 \mathrm{~cm}$, is attributed to the late AlbianCenomanian E. turriseiffelii/NC10/CC9 Zone. Cruciellipsis chiastia occurs consistently in this zone, indicating an age not younger than Cenomanian. The Albian/Cenomanian boundary can not be accurately identified using nannofossil events. Thierstein (1976) proposed the first occurrence of Lithraphidites acutus to define this boundary, 
but subsequent research (e.g., Verbeek, 1977; Perch-Nielsen, 1985) extended the range of this taxon into the Albian. This event was used by Roth (1978) to separate his Zone NC10 from Zone NC11. L. acutus was never observed at Site 800 and therefore the NC10/CC9 Zone was not identified. Sissingh (1977) proposed separating Zone CC9 from Zone $\mathrm{CC} 10$ on the first occurrence of Microrhabdulus decoratus. This taxon was also not observed at Site 800 . R. irregularis ranges as high as Sample 129-800A-16R-CC. Although the last occurrence of this species is not used as a datum plane in the adopted zonal schemes, according to Perch-Nielsen (1985) and Erba (1988) this taxon has its last appearance in the latest Albian. Consequently, the Albian/Cenomanian boundary might be placed above Sample 129. 800A-16R-CC.

Calcareous nannofossils are virtually absent in the remaining Cretaceous interval at Site 800, dated as Turonian-late Campanian on the basis of radiolarians.

\section{Site 801}

The Mesozoic of Site 801 extends from the Maestrichtian to the Callovian-Bathonian. In fact, this is the first DSDP/ODP drill site at which Jurassic sediments have been recovered from the Pacific Ocean. The sequence consists of cherts, porcellanites, claystones, and volcaniclastic turbidites, with minor calcareous pelagic intervals. Intensive investigation was performed on different lithologic types in order to document the occurrence of calcareous nannofossils in this unique oceanic site. Radiolarians are the most abundant and persistent group throughout the cored sequence, and the distribution of calcareous nannofossils is restricted to the middle Cretaceous interval and a few Jurassic samples (Table 3, back pocket).

The lowermost nannofossils observed from Hole 801B are rare specimens of Watznaueria manivitae that were encountered in Sample 129-801B-43R-3, 80-81 cm, in claystones entrapped within pillow lavas of lithostratigraphic Unit VI. W. manivitae first occurs in the lower Bajocian of several sections from France and Italy (Erba, 1990; Cobianchi et al., 1991) and extends into the Lower Cretaceous. The presence of $W$. manivitae in the lowermost part of the sequence drilled at Site 801 documents calcareous nannofossil production in the late Middle Jurassic of the Pacific Ocean. However, the scantiness of the nannofloras, induced by extremely severe dissolution, prevents estimating the flux rates of pelagic carbonates.

Only seven other Jurassic samples contain nannofossils. Rare specimens of the nondiagnostic species $W$. barnesae were observed in Samples 129-801B-33R-1, 94-95 cm, 129-801B-33R-1, $58 \mathrm{~cm}$, and 129-801B-33R-1, 18-19 cm. Sample 129-801B-33R-CC contains rare W. barnesae and one specimen of Biscutum erismaticum. This taxon was first observed in Oxfordian sediments from the Falkland Plateau (Wise and Wind, 1976), but its range was subsequently extended back to the Toarcian (Perch-Nielsen, 1985). Nannofossils observed in Sample 129-801B-26R-CC include $W$. barnesae, W. manivitae, Biscutum constans, Cretarhabdus sp., Polycostella beckmannii, and Cyclagelosphaera margerelii. P. beckmannii is a marker species restricted to the middle and late Tithonian (Thierstein, 1971, 1973, 1976; Bralower et al., 1989). This species is also present in Sample 129-801B-25R-CC where the relatively diverse nannoflora includes: $W$. barnesae, W. manivitae, W. communis, C. margerelii, B. constans, Discorhabdus rotatorius, Zygodiscus erectus, Vagalapilla stradneri, Umbria granulosa, Hexalithus noelae, Cretarhabdus sp., Parhabdolithus sp., Paleopontosphaera sp., and Nannoconus sp. We attribute this sample to the Hexalithus noelae Subzone of Bralower et al. (1989) of late Tithonian age. The age assignment of Samples 129-801B-26R-CC and 129-801B-25R$\mathrm{CC}$ is substantiated by the radiolarian biozones, which constitute the biostratigraphic framework for the sedimentary sequence at this site.

The rest of the Tithonian and the Lower Cretaceous from Samples 129-801B-25R-1, 56-57 cm, through 129-801B-10R-1, 65-66 cm, is barren of calcareous nannofossils. Pelagic calcareous layers from the volcaniclastic turbidites of lithostratigraphic Unit III yield rare to very abundant nannofloras. Assemblages are relatively diversified and preservation is poor to moderate. The occurrence of $L$. floralis and $P$. angustus and the absence of $P$. columnata point to the $P$. angustus/NC7 Zone of late Aptian age. Also at this site we noted a relative increase in the abundance of $R$. irregularis in the middle portion of this zone, and $A$. infracretacea is reported only from this interval. The first occurrence of $P$. columnata was observed in Sample 129-801B-8R-2, 28-29 cm, and was used to define the base of the $P$. columnata/NC8/CC 8 Zone. As previously discussed for Site 800 , the Aptian/Albian boundary can be placed in the upper part of the $P$. angustus/NC7 Zone. T. orionatus first occurs in Sample 129-801B-7R-CC and can be used to place the lower/middle Albian boundary. Other taxa that record their lowest appearance within the P. columnata Zone are Cribrosphaerella ehrenbergii, Prediscosphaera cretacea, and small Eiffellithus.

In Sample 129-801A-19R-CC Eiffellithus turriseiffelii has its first occurrence and is used to define the base of the E. turriseiffelii/ $\mathrm{NC10/CC9}$ Zone. The nannofossil assemblages are abundant and moderately preserved in this interval, which extends to Sample 129$801 \mathrm{~A}-14 \mathrm{R}-1,62-63 \mathrm{~cm}$. The absence of $L$. acutus and $M$. decoratus prevented the identification of the $\mathrm{NC11}$ and $\mathrm{CC} 10$ Zones. The occurrence of $C$. chiastia throughout this zone indicates an age not younger than Cenomanian; the Albian/Cenomanian boundary was placed between Cores 129-801A-15R and 129-801A-16R on the basis of the radiolarian distribution.

The Cenomanian-Maestrichtian interval corresponding to Cores 129-801A-13R through 129-801A-7R consists of cherts, porcellanites, and pelagic brown clays barren of calcareous nannofossils.

\section{Site $\mathbf{8 0 2}$}

The oldest sediments recovered at Site 802 consist of volcanic turbidites (lithostratigraphic Unit IX) and claystones (lithostratigraphic Unit VIII) containing rare, poorly preserved nannofossils (Table 4, back pocket). Assemblages consist of the dissolution/diagenesis-resistant species $W$. barnesae, $R$. terebrodentarius, and $P$. embergeri, which are not age diagnostic. However, the occurrence of $P$. angustus in Sample 129-802A-57R-1, 110-111 cm, indicates an age not older than late Aptian. This assignment is consistent with palynomorph biostratigraphy indicating a late Aptian-Albian age for Cores 129-802A-56R and 129-802A-57R.

Calcareous nannofossils become common to very abundant in the interval between Samples 129-802A-55R-CC and 129-802A-53R-1, $66-67 \mathrm{~cm}$, which is assigned to the $\mathrm{NC} 10-11 / \mathrm{CC} 9-10 \mathrm{Z}$ one. The base of the NC10/CC9 Zone is defined on the basis of the first occurrence of E. turriseiffelii in Sample 129-802A-55R-CC. C. chiastia is recorded up to Sample 129-802A-53R-1, 66-67 cm, indicating an age for this interval not younger than Cenomanian. Poorly preserved specimens of Lithraphidites acutus were observed in Samples 129$802 \mathrm{~A}-55 \mathrm{R}-1,16 \mathrm{~cm}$, and 129-802A-53R-CC. The first occurrence of this species is used to define the base of the $\mathrm{NC11} / \mathrm{CC} 10$ Zone, dated to the late Cenomanian. At Site $802 \mathrm{~L}$. acutus is too rare to consider its first appearance a reliable event and therefore we do not separate Zone $\mathrm{NC10}$ from Zone $\mathrm{NC11}$. Also $M$. decoratus was not observed in this interval and therefore we did not distinguish Zone CC10.

Cores $129-802 \mathrm{~A}-52 \mathrm{R}$ and $129-802 \mathrm{~A}-51 \mathrm{R}$ recovered claystones and radiolarites and are barren of calcareous nannofossils. The radiolarian assemblages from this interval belong to the $O$. somphedia Zone of Cenomanian-Turonian age (Matsuoka, this volume). A hiatus extending from the Cenomanian to the Coniacian is suspected.

In Sample 129-802A-51R-1, 89-90 cm, calcareous nannofossils are rare and poorly preserved, but Marthasterites furcatus occurs. In the zonal scheme adopted the first occurrence of this species is used to define the base of the $\mathrm{NC} 15 / \mathrm{CC} 13$ Zone correlatable to the 
Turonian/Coniacian boundary. This Zone extends through Sample $129-802$ A-50R-2, 83-86 cm. In the subsequent Sample 129-802A$50 \mathrm{R}-2,45-46 \mathrm{~cm}$, the first occurrence of Micula decussata was observed and, therefore, we placed the base of the CC14. This zone is short because it is limited to the interval from Samples 129-802A$50 \mathrm{R}-2,45-46 \mathrm{~cm}$, to $129-802 \mathrm{~A}-49 \mathrm{R}-3,107-109 \mathrm{~cm}$. The Coniacian/Santonian boundary falls within this zone.

Lithastrinus grillii was first observed in Sample 129-802A-49R$3,107-109 \mathrm{~cm}$. This event was used to place the boundary between Zones CC14 and CC15 as suggested by Perch-Nielsen (1985). The interval from this sample through Sample 129-802A-43R-1, 26-27 $\mathrm{cm}$, was attributed to the Santonian CC15-CC16Zones. Nannofossils are rare to very abundant, diversity relatively high, and preservation is poor to moderate. We did not find $L$. cayeuxii or $L$. septenarius and therefore could not separate Zone CC15 from Zone CC16.

A hiatus was identified between Cores 129-802A-43R and 129$802 \mathrm{~A}-42 \mathrm{R}$. In fact, several late Campanian marker species occur in Sample 129-802A-42R-CC. They include Ceratolithoides aculeus, Calculites obscurus, Quadrum gothicum, and Quadrum sissinghii. We attributed the interval between Samples 129-802A-42R-CC and 129-802A-38R-2, 129-130 cm, to the late Campanian CC21 Zone. The lower part of this interval contains rare and strongly dissolved nannofossil assemblages. Nannofloras become more abundant and better preserved in the upper part of this zone. In Sample 129-802A$38 \mathrm{R}-2,45-46 \mathrm{~cm}$, we used the first appearance of Quadrum trifidum to place the base of the late Campanian CC22 Zone. L. grillii has its last occurrence within this zone, in Sample 129-802A-38R-2, $29 \mathrm{~cm}$. The CC22 Zone extends to Sample 129-802A-38R-1, $1 \mathrm{~cm}$, which is the highest sample containing Cretaceous nannofossils.

\section{SUMMARY AND CONCLUSIONS}

The Jurassic and Cretaceous sequences recovered at Sites 800, 801 , and 802 were investigated for their calcareous nannofossil content. Light microscope analyses were performed on more than 500 samples from different lithologic facies. Calcareous nannofloras are usually not abundant and are poorly preserved. In fact, the Mesozoic sediments at these deep oceanic sites are dominated by chert, porcellanite, radiolarite, and claystone. Moreover, thick volcaniclastic turbidites were recovered in the middle and Upper Cretaceous interval.

We documented the occurrence, abundance, and preservation of calcareous nannofloras from the Bathonian to Campanian. Intervals barren of nannofossils or yielding only sparse solution-resistant taxa alternate with intervals containing abundant, moderately preserved assemblages with a relatively high diversity.

At Site 800 calcareous nannofossils provided the biostratigraphic framework for the Aptian-Albian interval. All the standard biozones were recognized.

Only very rare nannofossils were observed in the Jurassic sediments drilled at Site 801. Few specimens of W. manivitae were encountered in claystones from basement pillow lavas. A late Tithonian assemblage was recognized in two samples. The best nannofloras at this site come from the upper Aptian-Albian interval dated on the basis of nannofossil events.

The middle and Upper Cretaceous sequence recovered at Site 802 was dated with nannofossil biostratigraphy corroborated by radiolarian and palynomorph events in the middle Cretaceous. A hiatus was identified between the Santonian and the late Campanian and another one is suspected between the Cenomanian and the Coniacian.

\section{ACKNOWLEDGMENTS}

We sincerely thank Y. Lancelot, R. Larson, and the Leg 129 scientific party for cooperation, support, and discussion. The manuscript benefited from the critical comments of Katharina von Salis Perch-Nielsen and Hans Thierstein, which are gratefully acknowledged. Research was supported by CNR funds to E.E.

\section{REFERENCES}

Arkhangelsky, A. D., 1912. Verkhnemielovyya otlozheniya vostoka evropeyskoy Rossii. (Upper Cretaceous Deposits of East European Russia). Mater. Geol. Ross., 25:1-631.

Barnard, T., and Hay, W. W., 1974. On Jurassic coccoliths: a tentative zonation of the Jurassic of southern England and north France. Eclogae Geol. Helv., 67:563-585.

Black, M., 1967. New names for some coccolith taxa. Proc. Geol. Soc. London, 1640:139-145.

, 1971. Coccoliths of the Speeton Clay and Sutterby Marl. Proc. Yorkshire Geol. Soc., 38:381-424.

, 1973. British Lower Cretaceous Coccoliths. I. Gault Clay, Part 2. Palaeontol. Soc. Monogr., 49-112.

Black, M., and Barnes, B., 1959. The structure of coccoliths from the English Chalk. Geol Mag., 96:321-328.

Bown, P. R., 1987. Taxonomy, evolution, and biostratigraphy of Late TriassicEarly Jurassic Calcareous Nannofossils. Spec. Pap. Paleontol., 38:1-118.

Bown, P. R., Cooper, M.K.E., and Lord, A. R., 1988. A calcareous nannofossil biozonation scheme for early to mid Mesozoic. Newsl. Stratigr, 20:91-114.

Bralower, T. J., 1987. Valanginian to Aptian calcareous nannofossil stratigraphy and correlation with the upper M-sequence magnetic anomalies. Mar. Micropaleontol., 11:293-310.

Bralower, T. J., Bown, P. R., and Siesser, W. G., 1991. Significance of Upper Triassic nannofossils from the Southern Hemisphere (ODP Leg 122, Wombat Plateau, N.W. Australia). Mar. Micropaleontol., 17:119-154.

Bralower, T. J., Monechi, S., and Thierstein, H. R., 1989. Calcareous nannofossil zonation of the Jurassic-Cretaceous boundary interval and correlation with the geomagnetic polarity timescale. Mar. Micropaleontol., 14:153-235.

Bramlette, M. N., and Martini, E., 1964. The great change in calcareous nannoplankton fossils between the Maestrichtian and Danian. Micropaleontology, 10:291-322.

Brönnimann, P., 1955. Microfossils Incertae sedis from the Upper Jurassic and Lower Cretaceous of Cuba. Micropaleontology, 1:28-51.

Bukry, D., 1969. Upper Cretaceous coccoliths from Texas and Europe. Univ. Kansas Paleontol. Contrib., 51:1-79.

, 1973. Coccolith stratigraphy Leg 10, Deep Sea Drilling Project. In Worzel, J. L., Bryant, W., et al., Init. Repts. DSDP, 10: Washington (U.S. Govt. Printing Office), 385-406.

Bukry, D., and Bramlette, M. N., 1969. Coccolith age determination Leg 3, Deep Sea Drilling Project. In Maxwell, A. E., Von Herzen, R. P., et al., Init. Repts. DSDP, 3: Washington (U.S. Govt. Printing Office), 589-611.

Channell, J.E.T., and Erba, E., in press. Early Cretaceous polarity Chrons CM0 to CM11 recorded in Northern Italian land sections near Brescia (Northern Italy). Earth Planet. Sci. Lett.

Cobianchi, M., Erba, E., and Pirini Radrizzani, C., 1991. Evolutionary trends of calcareous nannofossil genera Lotharingius and Watznaueria during the Early and Middle Jurassic. Mem. Sci. Geol., 43:19-25.

Colom, G., 1948. Fossil tintinnids: Loricated Infusoria of the order of the Oligotricha. J. Paleontol., 22:233-263.

Covington, J. M., and Wise, S. W., Jr., 1987. Calcareous nannofossil biostratigraphy of a Lower Cretaceous deep-sea fan complex: Deep Sea Drilling Project Leg 93 Site 603, lower continental rise off Cape Hatteras. In Van Hinte, J. E., Wise, S. W., Jr., et al., Init. Repts. DSDP, 93: Washington (U.S. Govt. Printing Office), 617-660.

Crux, J.A., 1981. New calcareous nannofossils taxa from the Cretaceous of South East England. Neues Jahrb. Geol. Palaeontol. Monatsh., 10:633-64. , 1982. Upper Cretaceous (Cenomanian to Campanian) calcareous nannofossils. In Lord, A. R. (Ed.), A Stratigraphical Index of Calcareous Nannofossils. Brit. Micropaleontol. Soc. Ser., 81-135.

1987. Six new species of calcareous nannofossils from the Lower Cretaceous strata of England and Germany. INA Newsl., 9:30-35.

- 1989. Biostratigraphy and palaeogeographical applications of Lower Cretaceous nannofossils from north-western Europe. In Crux, J. A., and van Heck, S. E. (Eds.), Nannofossils and Their Applications. Brit. Micropaleontol. Soc. Ser., 143-211.

Deflandre, G., 1959. Sur les nannofossiles calcaires et leur systématique. Rev. Micropaleontol., 2:127-152.

1963. Sur les Microrhabdulites, famille nouvelle des Nannofossiles calcaires. C. R. Acad. Sci. Ser. 2, 256:3484-3486.

Deflandre, G., and Fert G., 1954. Observations sur les Coccolithophorides actuels et fossiles en microscopie ordinaire et electronique. Ann. Paleontol., 40:115-176. 
De Lapparent, J., 1931. Sur les prétendus "embryons de Lagena." C. R. Soc. Geol. Fr., 1931:222-223.

Deres, F., and Acheriteguy, J., 1980. Biostratigraphie des Nannoconides. Bull. Cent. Rech. Explor.-Prod. Elf-Aquitaine, 4:1-53.

Erba, E., 1988. Aptian-Albian calcareous nannofossil biostratigraphy of the Scisti a Fucoidi cored at Piobbico (Central Italy). Riv. Ital. Paleontol. Stratigr., 94:249-284

-1990. Calcareous nannofossil biostratigraphy of some Bajocian sections from the Digne area (SE France). Mem. Descr. Carta Geol. Ital., 40:237-256.

Gartner, S., 1968. Coccoliths and related calcareous nannofossils from Upper Cretaceous deposits of Texas and Arkansas. Univ. Kansas Paleontol. Contrib., 48:1-56.

Gorka, H., 1957. Coccolithophoridae z gornego mastrychtu Polski srodkowej (Les Coccolithophoridés du Maastrichtien superieur de Pologne). Acta Palaeontol. Polon., 2:235-284.

Grün, W., and Zweili, F., 1980. Das kalkige Nannoplankton der Dogger-MalmGrenze im Berner Jura bei Liesberg (Schweiz). Jahrb. Geol. Bundesanst Austria, 123:213-341.

Hill, M. E., 1976. Lower Cretaceous calcareous nannofossils from Texas and Oklahoma. Palaeontographica B, 156:103-179.

Jakubowski, M., 1987. A proposed Lower Cretaceous calcareous nannofossil zonation scheme for the Moray Firth area of the North Sea. Abh. Geol. Bundesanst (Austria), 39:99-119.

Kamptner, E., 1938. Einige Bemerkungen über Nannoconus. Palaontol. Z., 20:249-257.

Kent, D. V., and Gradstein, F. M., 1985. A Cretaceous and Jurassic geochronology, Geol. Soc. Am. Bull., 96:1419-1427.

Lancelot, Y., Larson, R. L., et al., 1990. Proc. ODP, Init. Repts,, 129: College Station, TX (Ocean Drilling Program).

Loeblich, A. R., and Tappan, H., 1963. Type fixation and validation of certain calcareous nannoplankton genera. Proc. Biol. Soc. Wash., 76:191-196.

Manivit, H., 1965. Nannofossiles calcaires de l'Albo-Aptien. Rev. Micropaleontol., 8:189-201.

1966. Sur quelques coccolithes nouveaux du Neocomien. C.R. Soc. Geol. Fr. 7:267-268.

1971. Nannofossiles calcaires du Crétacé Francais (Aptien-Maastrichtien). Essai de biozonation appuyee sur les stratotypes [These Doctorate d'Etat]. Fac. Sci d'Orsay.

Manivit, H., Perch-Nielsen, K., Prins, B., and Verbeek, J. W., 1977. Mid-Cretaceous calcareous Proc. K. Ned. Akad. Wet., Ser. B: Palaeontol., Geol, Phys., Chem., 80:169-181.

Martini, E., and Stradner, H., 1960. Nannotetraster, eine stratigraphisch bedeutsame neue Discoasteridengattung. Erdoel-Z, 76:266-270.

Medd, A. W., 1982. Nannofossil zonation of the English Middle and Upper Jurassic. Mar. Micropaleontol., 7:73-95.

Monechi, S., and Thierstein, H. R., 1985. Late Cretaceous-Eocene nannofossil and magnetostratigraphic correlations near Gubbio, Italy. Mar. Micropaleontol., 9:419-440.

Mortimer, C. P., 1987. Upper Cretaceous calcareous Nannofossil Biostratigraphy of the Southern Norwegian and Danish North Sea Area. Abh. Geol. Bundesanst (Austria), 39:143-175.

Moshkovitz, S., and Ehrlich, A., 1987. Watznaueria manivitae, Bukry-Taxonomic problems and distribution in the Jurassic-Lower Cretaceous sediments of Israel and other Tethyan areas. INA Newsl., 9:110-115.

Noël, D., 1957. Coccolithes des terrains Jurassiques de Algerie. Publ. Serv. Carte Geol. Algerie, 2:303-345.

, 1958. Etude de Coccolithes du Jurassique et Crétacé inferieur. Bull. Serv. Carte Geol. Algerie, 2:155-196.

1965. Coccolithes jurassiques. Essai de classification des Coccolithes fossiles. Ed. C.N.R.S., 209.

- 1969. Structure de quelques coccolithes du Crétacé superieur du Bassin de Paris examinés au microscope electronique. Proc. Ist Int. Conf. Planktonic Microfossils, Geneve 1967, 2:475-485.

Perch-Nielsen, K., 1968. Der Feinbau und die Klassifikation der Coccolithen aus dem Maastrichtien von Dänemark. Biol. Skr. K. Danske Vidensk., 16:1-96.

1979. Calcareous nannofossils from the Cretaceous between the North Sea and the Mediterranean. In Wiedmann, J. (Ed.), Aspekte der Kreide Europas. IUGS Ser. A, 6:223-272.

, 1985. Mesozoic calcareous nannofossils. In Bolli, H. M., Saunders, J. B., and Perch-Nielsen, K. (Eds.), Plankton Stratigraphy: Cambridge (Cambridge Univ. Press), 329-426.
1986. New Mesozoic and Paleogene calcareous nannofossils. Eclogae Geol. Helv, 79:835-847.

Piveteau, J., 1952. Traité de Paléontologie, v. 1: Classe de Coccolithophoridés. Masson, 107-115.

Reinhardt, P., 1964. Einige Kalkflagellaten Gattungen (Coccolithophoriden, Coccolithineen) aus dem Mesozoikum Deutschlands. Monatsber. Deut. Akad. Wiss. Berlin, 6:749-759.

1965. Neue Familien für fossile Kalkflagellaten (Coccolithophoriden, Coccolithineen). Monatsber. Dtsch. Akad. Wiss. Berlin, 7:30-40.

, 1966. Zur Taxinomie und Biostratigraphie des fossilen Nannoplanktons aus dem Malm, der Kreide und dem Alttertiär Mitteleuropas. Freiberg. Forschungsh. C, 196:1-109.

, 1970. Synopsis der Gattungen und Arten der mesozoischen Coccolithen und anderer Kalkiger Nannofossilien. Teil II. Freiberg. Forschungsh. C, 625:41-111.

Rood, A. P., Hay, W. W., and Barnard, T., 1971. Electron microscope studies of Oxford clay coccoliths. Eclogae Geol. Helv., 64:245-272.

Roth, P. H., 1973. Calcareous nannofossils. In Winterer, E. L., Ewing, J. L., et al., Init. Repts. DSDP, 17: Washington (U.S. Govt. Printing Office), 695-793.

, 1978. Cretaceous nannoplankton biostratigraphy and oceanography of the northwestern Atlantic Ocean. In Benson, W. E., Sheridan, R. E., et al., Init. Repts. DSDP, 44: Washington (U.S. Govt. Printing Office), $731-759$.

- 1983. Jurassic and Lower Cretaceous calcareous nannofossils in the Western North Atlantic (Site 534): biostratigraphy, preservation, and some observations on biogeography and paleoceanography. In Sheridan, R. E., Gradstein, F. M., et al., Init. Repts. DSDP, 76: Washington (U.S. Govt. Printing Office), 587-621.

Roth, P. H., Medd, A. W., and Watkins, D. K., 1983. Jurassic calcareous nannofossil zonation, an overview with new evidence from Deep Sea Drilling Project Site 534. In Sheridan, R. E., Gradstein, F. M., et al., Init. Repts. DSDP, 76: Washington (U.S. Govt. Printing Office), 573-579.

Roth, P. H., and Thierstein, H. R., 1972. Calcareous nannoplankton. In Hayes, D. E., Pimm, A. C., et al., Init. Repts. DSDP, 14: Washington (U.S. Govt. Printing Office), 421-485.

Shafik, S., and Stradner, H., 1971. Nannofossils from the Eastern Desert, Egypt, with reference to Maastrichtian nannofossils from the USSR. Jahrb. Geol. Bundesanst. Austria, 17:69-104.

Sissingh, W., 1977. Biostratigraphy of Cretaceous calcareous nannoplankton. Geol. Mijnbouw, 56:37-65.

Stover, L. E., 1966. Cretaceous coccoliths and associated nannofossils from France and the Netherlands. Micropaleontology, 12:133-167.

Stradner, H., 1961. Vorkommen von Nannofossilien im Mesozoikum und Alttertiär. Erdoel-Z., 77:77-88.

, 1962. Über neue und wenig bekannte Nannofossilien aus Kreide und Alttertiär. Verh. Geol. Bundesanst. (Austria), 1962:363-376.

1963. New contributions to Mesozoic stratigraphy by means of nannofossils. Proc. 6th World Petrol. Congr., Sect. 1, Pap. 4:1-16.

Stradner, H., Adamiker, A., and Maresch, O., 1968. Electron microscope studies on Albian calcareous nannoplankton from the Delft 2 and Leidschenden 1 Deepwells, Holland. Verh. K. Akad. Wetensch. Afd. Natuurk., 24:1-107.

Stradner, H., and Steinmetz, J., 1984. Cretaceous calcareous nannofossils from the Angola Basin, Deep Sea Drilling Project Site 530. In Hay, W. W., Sibuet, J. C., et al., Init. Repts. DSDP, 75: Washington (U.S. Govt. Printing Office), 565-649.

Thierstein, H. R., 1971. Tentative Lower Cretaceous calcareous nannoplankton zonation. Eclogae Geol. Helv., 64:459-488.

, 1973. Lower Cretaceous calcareous nannoplankton biostratigraphy. Abh. Geol. Bundesanst. (Austria), 29:1-52.

, 1976. Mesozoic calcareous nannoplankton biostratigraphy of marine sediments. Mar. Micropaleontol., 1:325-362.

Trejo, M., 1969. Conusphaera mexicana, un nuevo coccolitoforido del Jurassico superior de Mexico. Rev. Inst. Mexicano Petrol., 1:5-15.

Vekshina, V. N., 1959. Kokkolitoforidy maastrikhtskikh otlozhenii ZapadnoSibiriskoi nizmennosti (Coccolithophoridae of the Maastrichtian deposits of the west Siberian lowland). Trudy Sibir. Nauch.-Issled. Inst. Geol. Geofiz. Min. Syr'ya, 2:56-81.

Verbeek, J. W., 1977. Calcareous nannoplankton biostratigraphy of Middle and Upper Cretaceous deposits in Tunisia, Southern Spain and France. Utrecht Micropaleontol. Bull., 6:1-57.

Wind, F. H., and Cepek, P., 1979. Lower Cretaceous calcareous nannoplankton from DSDP Hole 397A (Northwest African Margin), In von Rad, U., Ryan, 
W.B.F., et al., Init. Repts. DSDP, 47: Washington (U.S. Govt. Printing Office), 241-255.

Wise, S. W., Jr., and Wind, F. H., 1976. Mesozoic and Cenozoic calcareous nannofossils recovered by Deep Sea Drilling Project Leg 36 drilling on the Falkland Plateau, Southwest Atlantic sector of the Southern Ocean. In Barker, P. F., Dalziel, LW.D., et al., Init. Repts. DSDP, 36: Washington (U.S. Govt. Printing Office), 269-491.

Worsley, T., 1971. Calcareous nannofossil zonation of Upper Jurassic and Lower Cretaceous sediments from the Western Atlantic. Proc. 2nd Planktonic Conf. Roma, 2:1301-1322.

\section{Date of initial receipt: 30 May 1991 \\ Date of acceptance: 17 March 1992 \\ Ms 129B-118}

\section{APPENDIX}

Species of Jurassic and Cretaceous nannofossils recognized in this study are listed in alphabetical order by species epithet. Reported for each taxon are: the author(s) who defined the species, possible subsequent author(s) who emended the species, and references to original illustration(s) of the species or the illustration(s) closest to the species concepts used in this study.

Parhabdolithus achlyostaurion Hill, 1976, pl. 9, figs. 24-29.

Corollithion achylosum (Stover, 1966) Thierstein, 1971. Stover, 1966, pl. 6, fig. 26; pl. 7, figs. 1-3; pl. 9, fig. 20. Thierstein, 1971, pl. 7, figs. 12-16.

Ceratolithoides aculeus (Stradner, 1961) Prins and Sissingh in Sissingh, 1977. Stradner, 1961, figs. 53-57. Thierstein, 1976, pl. 5, figs. 22, 23.

Braarudosphaera africana Stradner, 1961, text-fig. 44. Hill, 1976, pl. 2 , figs. 10-13.

Lithraphidites alatus Thierstein in Roth and Thierstein, 1972. Thierstein, 1976, pl. 4 , figs. 26,27 .

Axopodorhabdus albianus (Black, 1967) Wind and Wise in Wise and Wind, 1976. Thierstein, 1976, pl. 4, figs. 13, 14.

Cretarhabdus angustiforatus (Black, 1971) Bukry, 1973. Black, 1971, pl. 33, fig. 4. Bukry, 1973, pl. 2, figs. 4-7. Thierstein, 1976, pl. 3, figs. 1, 2

Parhabdolithus angustus (Stradner, 1963) Stradner, Adamiker, and Maresch, 1968. Stradner, 1963, pl. 5, fig. 6. Stradner et al., 1968, pl. 20. Thierstein, 1976, pl. 4, figs. $1,2$.

Reinhardtites anthophorus (Deflandre, 1959) Perch-Nielsen, 1968. Sissingh, 1977, pl. 1, figs. 5a-5d.

Lithastrinus antiquus Perch-Nielsen, 1979, pl. 1, figs. 5-9.

Parhabdolithus asper (Stradner, 1963) Manivit, 1971. Stradner, 1963, pl. 2. figs. 4, 5. Manivit, 1971, pl. 23, figs. 4-7.

Watznaueria barnesae (Black in Black and Barnes, 1959) Perch-Nielsen, 1968. Black and Barnes, 1959, pl. 9, figs. 1, 2. Perch-Nielsen, 1968, pl. 22, figs. $1-7$; pl. 23 , figs. $1,4,5,16$.

Polycostella beckmannii Thierstein, 1971, pl. 2, figs. 5-16.

Biscutum blackii Gartner, 1968, pl. 1, fig. 7; pl. 6, figs. 2a-2c; pl. 8, figs. 8, 9; pl. 11 , figs. $8 \mathrm{~A}-8 \mathrm{C}$.

Watznaueria britannica (Stradner, 1963) Reinhardt, 1964. Stradner, 1963, pl. 1, figs. 7, 7a. Reinhardt, 1964, pl. 2, fig. 3. Thierstein, 1976, pl. 4, figs. 24,25 .

Lithraphidites carniolensis Deflandre, 1963, text-figs. 1-10. Thierstein, 1976, pl. 2 , figs. 33,34

Cruciellipsis chiastia (Worsley, 1971) Thierstein in Roth and Thierstein, 1972. Worsley, 1971, pl. 1, figs. 42-44. Roth and Thierstein, 1972, pl. 6, figs. $8-13$.

Markalius circumradiatus (Stover, 1966) Perch-Nielsen, 1968. Stover, 1966. pl. 5, figs. 2, 4; pl. 9, fig. 10. Perch-Nielsen, 1968, pl. 25, figs. 2-7; pl. 26 , figs. $1-7$.

Nannoconus colomii (De Lapparent, 1931) Kamptner, 1938. Colom, 1948, fig. 7. Thierstein, 1971, pl. 3, fig. 16. Deres and Acheriteguy, 1980, pl. 2, figs. 4, 9; pl. 3, fig. 1

Prediscosphaera columnata (Stover, 1966) Manivit, 1971. Stover, 1966, pl. 6, figs. 6-10; pl. 9, fig. 16. Manivit, 1971, pl. 21, figs. 13-15. Manivit et al., 1977, pl. 1, fig. 2 .

Watznaueria communis Reinhardt, 1964, pl. 2, fig. 5.

Micula concavata (Stradner in Martini and Stradner, 1960) Bukry, 1969 Martini and Stradner, 1960, figs. 18a-18d. Perch-Nielsen, 1985, fig. 58.20.

Cretarhabdus conicus Bramlette and Martini, 1964, pl. 3, figs. 5-8. Thierstein, 1971, pl. 6, figs. 7-12.
Biscutum constans (Gorka, 1957) Black, 1967. Gorka, 1957, pl. 4, fig. 7. Roth and Thierstein, 1972, pl. 8, figs. 13-18.

Prediscosphaera cretacea (Arkhangelsky, 1912) Gartner, 1968. Arkhangelsky, 1912, pl. 6, figs. 12, 13. Thierstein, 1976, pl. 4, figs. 5, 6.

Cruciellipsis cuvillieri (Manivit, 1966) Thierstein, 1971.Thierstein, 1971, pl. 5, figs. 4-8.

Arkhangelskiella cymbiformis (Vekshina, 1959) Reinhardt, 1964. Reinhardt, 1964, pl. 1, figs. 1, 2; text-fig. 3.

Micrantholithus decoratus Deflandre, 1959, pl. 4, fig. 1-5. Thierstein, 1976, pl. 5, figs. 1,2

Micula decussata Vekshina, 1959, pl. 1, fig. 6; pl. 2, fig. 11.

Zygodiscus diplogrammus (Deflandre in Deflandre and Fert, 1954) Gartner, 1968. Deflandre and Fert, 1954, pl. 10, fig. 7. Gartner, 1968, pl. 21, fig. 2; pl. 22 , fig. 7 .

Cribrosphaerella ehrenbergii (Arkhangelsky, 1912) Deflandre in Piveteau, 1952. Arkhangelsky, 1912, pl. 6, figs. 19, 20. Thierstein, 1976, pl. 4, figs. 17-20.

Zygodiscus elegans (Gartner, 1968) Bukry, 1969. Gartner, 1968, pl, 10, fig. 3-6; pl. 12, figs. 3, 4; pl. 27, fig. 1. Hill, 1976, pl. 12, figs. 23-24.

Parhabdolithus embergeri (Noël, 1958) Stradner, 1963. Noël, 1958, pl. 1, figs. 1, 7, 8. Stradner, 1963, pl. 8, fig. 1 .

Zygodiscus erectus (Deflandre in Deflandre and Fert, 1954) Bukry and Bramlette, 1969. Deflandre and Fert, 1954, pl. 15, figs. 14-17.

Biscutum erismaticum (Wind and Wise in Wise and Wind, 1976) Grün and Zweili, 1980. Wise and Wind, 1976, pl. 78, figs. 4-6.

Corollithion exiguus Stradner, 1961, text-figs. 58-61. Perch-Nielsen, 1985, figs. 69.5-69.7.

Eiffellithus eximius (Stover, 1966) Perch-Nielsen, 1968. Stover, 1966, pl. 2 , figs. 15, 16. Perch-Nielsen, 1968, pl. 3, figs. 8-10. Thierstein, 1976, pl. 5, figs. 28-29.

Reinhardtites fenestratus (Worsley, 1971) Thierstein in Roth and Thierstein, 1972. Worsley, 1971, pl. 1, figs. 33-35. Roth and Thierstein, 1972, pl. 8, figs. 1-12. Thierstein, 1976, pl. 3, figs. 3, 4 .

Lithastrinus floralis Stradner, 1962, pl. 2, figs. 6-11. Thierstein, 1976, pl. 5, figs. $14-16$.

Marthasterites furcatus (Deflandre in Deflandre and Fert, 1954) Deflandre, 1959. Deflandre and Fert, 1954, pl. 13, fig. 14. Thierstein, 1976, pl. 5, fig. 3.

Broinsonia furtiva Bukry, 1969, pl. 2, figs 7, 8 .

Tranolithus gabalus Stover, 1966, pl. 4, fig. 22.

Quadrum gartneri Prins and Perch-Nielsen in Manivit et al., 1977, pl. 1, figs. 9,10 .

Eiffellithus gorkae Reinhardt, 1965, pl. 2, fig. 2, text-fig. 6. Perch-Nielsen, 1985 , figs. $35.13,35.16$.

Quadrum gothicum (Deflandre, 1959) Prins and Perch-Nielsen in Manivit et al., 1977. Deflandre, 1959, pl. 3, fig. 25. Thierstein, 1976, pl. 5, figs. 24, 25.

Prediscosphaera grandis Perch-Nielsen, 1979, pl. 2, fig. 9.

Umbria granulosa Bralower and Thierstein in Bralower et al., 1989, pl. 1, figs. $1-15$.

Lithastrinus grillii Stradner, 1962, pl. 2, figs. 1-5. Thierstein, 1976, pl. 5, figs. 4,5 .

Bukryaster hayi (Bukry, 1969) Prins and Sissingh in Sissingh, 1977. Bukry, 1969, pl. 38, figs. 10-12. Perch-Nielsen, 1985, figs. 22.15, 22.16.

Rucinolithus hayi Stover, 1966, pl. 7, fig, 21.

Micrantholithus hoschulzii (Reinhardt, 1966) Thierstein, 1971. Reinhardt, 1966, pl. 21, fig. 3. Thierstein, 1971, pl. 1, figs. 12-15.

Assipetra infracretacea (Thierstein, 1973) Roth, 1973. Thierstein, 1973, pl. 1, figs. 1-19. Roth, 1973, pl. 25 , figs. $5,7,9$.

Rucinolithus irregularis Thierstein in Roth and Thierstein, 1972, pl. 2, figs. 10-19; Thierstein, 1973, pl. 3, figs. 1-14.

Stephanolithion laffittei Noël, 1957, pl. 2, fig. 5. Thierstein, 1976, pl. 2, figs. 31-32.

Diazomatolithus lehmanii Noël, 1965, pl. 6, figs. 6-10. Thierstein, 1971, pl. 3, figs. $11-15$.

Chiastozygus litterarius (Gorka, 1957) Manivit, 1971. Gorka, 1957, pl. 3, fig. 3; Manivit, 1971, pl. 4, fig. 1-5. Thierstein, 1976, pl. 3, figs. 31, 32.

Kamptnerius magnificus Deflandre, 1959, pl. 1, fig. 1-4. Thierstein, 1976, pl. 6 , figs. 38-39.

Watznaueria manivitae Bukry, 1973. Moshkovitz and Ehrlich, 1987, pl. 1, figs. $1-11$.

Cyclagelosphaera margerelii Noël, 1965, text-fig. 45-48; Roth and Thierstein 1972, pl. 16, figs. 19-22.

Conusphaera mexicana Trejo,1969, pl. 1, figs. 1-9; pl. 2, figs. 1-8; pl. 3, figs. 1-7; pl. 4, figs. 1-4; Thierstein, 1976, pl. 2, figs. 26, 27. 
Hexalithus noelae (Noël, 1957) Loeblich and Tappan, 1963. Noël, 1957, pl. 5 , figs. 39,40 .

Flabellites oblongus (Bukry, 1969) Crux, 1982. Bukry, 1969, pl. 11, figs. 8-10. Thierstein, 1973, pl. 5, figs. 1-12. Crux, 1982, pl. 5.1, fig. 11; pl. 5.8, fig. 1 .

Calculites obscurus (Deflandre, 1959) Prins and Sissingh in Sissingh, 1977. Deflandre, 1959, pl. 3, figs. 26-29. Thierstein, 1976, pl. 5, figs. 10-11.

Amuhellerella octoradiata (Gorka, 1957) Reinhardt, 1964. Reinhardt, 1964. pl. 1, fig. 2. Perch-Nielsen, 1985, figs. 12.15, 12.16, 12.24 .

Tranolithus orionatus (Reinhardt, 1966) Perch-Nielsen, 1968. Reinhardt, 1966, pl. 23, figs. 22, 31-33. Thierstein, 1976, pl. 4, figs. 11, 12.

Aspidolithus parcus (Stradner, 1963) Noël, 1969. Stradner, 1963, pl. 1, fig. 3. Thierstein, 1976, pl. 5, figs. 20, 21.

Manivitella pemmatoidea (Deflandre in Manivit, 1965) Thierstein, 1971. Manivit, 1965, pl. 2, fig. 8. Thierstein, 1971, pl. 5, figs. 1-3.

Micula praemurus (Bukry, 1973) Stradner and Steinmetz, 1984. Bukry, 1973, pl. 2, figs. 6-9.

Parhabdolithus pseudoangustus Crux, 1987, pl. 1, figs. 4, 5, 16, 17.

Lithraphidites pseudoquadratus Crux, 1981, text-fig. 1, n. 1-4.

Braarudosphaera regularis Black, 1973, pl. 28, fig. 10.

Discorhabdus rotatorius (Bukry, 1969) Thierstein, 1973. Bukry, 1969, pl. 27, figs. 5-9. Thierstein, 1973, pl. 5, figs. 13-16.

Cylindralithus serratus Bramlette and Martini, 1964, pl. 5, figs. 18-20.

Quadrum sissinghii Perch-Nielsen, 1986, pl. 3, figs. 3-5.

Prediscosphaera spinosa (Bramlette and Martini, 1964) Gartner, 1968. Bramlette and Martini, 1964, pl. 2, figs. 17-20.
Zygodiscus spiralis Bramlette and Martini , 1964, pl. 4, figs. 6-8; Hill, 1976, pl. 12 , figs. $28-37$.

Prediscosphaera stoveri (Perch-Nielsen, 1968) Shafik and Stradner, 1971. Perch-Nielsen, 1985, fig. 61.37.

Tegumentum stradneri Thierstein in Roth and Thierstein, 1972, pl. 1, figs. 7-15. Vagalapilla stradneri (Rood, Hay, and Barnard, 1971) Thierstein, 1973. Rood et al., 1971, pl. 1, fig. 2.

Cretarhabdus striatus (Stradner, 1963) Black, 1973. Stradner, 1963, pl. I, fig. 1.

Watznaueria supracretacea (Reinhardt, 1965) Wind and Wise in Wise and Wind, 1976. Reinhardt, 1965, pl. 2, figs. 7, 8. Wise and Wind, 1976, pl. 50, fig. 8; Hill, 1976, pl. 2, figs. 1-9.

Cretarhabdus surirellus (Deflandre in Deflandre and Fert, 1954) Reinhardt, 1970. Deflandre and Fert, 1954, pl. text-figs. 30, 31. Reinhardt, 1970, pl. 1, fig. 8; pl. 2, fig. 6. Thierstein, 1971, pl. 6, figs. 1-6.

Parhabdolithus swinnertonii (Black, 1971) Wind and Cepek, 1979. Black, 1971, pl. 34, fig. 4. Wind and Cepek, 1979, pl. 11, figs. 8-16.

Rucinolithus terebrodentarius Applegate, Bralower, Covington and Wise, in Covington and Wise 1987, pl. 17, figs. 7, 8; pl. 18, figs. 5-7; pl. 19, figs. 1-4. Quadrum trifidus (Stradner, 1961) Prins and Perch-Nielsen in Manivit et al., 1977. Stradner, 1961, pl. 23, fig. 3. Thierstein, 1976, pl. 5, figs. 26, 27.

Nannoconus truittii Brönnimann, 1955, pl. 2, figs. 2-5, 7.

Eiffellithus turriseiffelii (Deflandre in Deflandre and Fert, 1954) Reinhardt, 1965. Deflandre and Fert, 1954, pl. 13, fig. 15, 16. Thierstein, 1976, pl. 4, figs. $15,16$.

Pervilithus varius Crux, 1981, text-fig. 1, n. 6-9; text-fig. 2, n. 9.

Ceratolithoides verbeekii Perch-Nielsen, 1979, pl. 2, figs. 10-13. 